\title{
MORPHOLOGICAL STUDY OF VARIATIONS IN FORAMEN TRANSVERSARIUM OF ATLAS VERTEBRA
}

\author{
Hina Kausar, Alok Tripathi, Ajay Kumar, Satyam Khare, Shilpi Jain, Ram Kumar Kaushik, Saurabh Arora \\ Department of Anatomy, Subharti Medical College, Meerut, UP, India
}

\begin{abstract}
Introduction: Foramen transversarium are the characteristic bony feature of the cervical vertebrae. They are located on the transverse process of cervical vertebrae through which second part of vertebral artery passes along with vertebral venous and sympathetic plexus. Their variations are common with regard to size, shape, incomplete, duplicated and may even absent.
\end{abstract}

Material \& Methods: Two hundred foramen transversarium of one hundred atlas vertebrae were examined for morphological variations.

Results: Out of hundred atlas vertebrae examined, foramen transversarium was present in all. Absence of costal element was noticed in four atlas vertebrae. Four atlas vertebrae showed incomplete bilateral foramen transversarium while four showed unilateral duplicated foramen transversarium.

Conclusion: The increasing incidence of neck injuries and related syndromes necessitates the study of bony variations of the atlas vertebra and its foramen transversarium. The second part of vertebral artery is prone to be damaged during neck surgeries and posterior cervical injuries due to incomplete formation of the foramen transversarium, hence the knowledge of such variations is important for surgeons, otorhinolaryngologists, neurologists, orthopedicians, radiologists and physicians.

Keywords: Foramen transversarium, atlas vertebrae, vertebral artery.

\section{INTRODUCTION}

Atlas, the first cervical vertebra supports the globe of the head and hence its name. It differs from other cervical vertebrae in lacking a body; and spine, with large lateral mass on both sides, and the two transverse processes are widest apart relative to other cervical vertebrae [1].

The second part of the vertebral artery passes through foramen transversarium of $\mathrm{C} 6-\mathrm{C} 1$ along with vertebral venous plexus and sympathetic plexus, it then enters the foramen magnum and joins with the corresponding vertebral artery to form basilar artery [1]. The atlas vertebra differs in structure from other cervical vertebrae and variations of this vertebrae are common. In the past, various studies has been conducted by many authors on the variations in size, shape, absence, incomplete [2-5] or duplicated foramen transversarium [6-8].

Such variations in the foramen transversarium may cause compression of vertebral artery during manipulation of cervical spine surgery, excessive exercise of the neck, physiotherapy and this may result in vertebro-basilar ischemia which may lead to common symptoms like migrane, vertigo, diplopia, shoulder pain, neck pain and sometime cerebrovascular incidents [8]. Hence, the knowledge of variation of foramen transversarium of atlas vertebrae is important for physicians, surgeons, orthopedicians, neurologists and physiotherapists [5].

Address for Correspondence:

Dr Alok Tripathi, Assistant Professor, Department of Anatomy, Subharti Medical College, Swami Vivekanand Subharti University, N.H.-58, Delhi-Haridwar By Pass Road, Meerut, UP, India - 250005. Mob: 7055762619, 7409468058 Email: draloktripathi.80@gmail.com 


\section{MATERIALS AND METHODS}

One hundred atlas vertebrae of unknown sex of North Indian population were studied in the Department of Anatomy, Subharti Medical College, Meerut, Uttar Pradesh, India. Foramen transversarium were studied for presence, absence, incomplete and duplication in one hundred atlas vertebra.

\section{OBSERVATIONS AND RESULTS}

Out of one hundred atlas vertebrae examined, foramen transversarium were present in all of the vertebrae. Foramen transversarium was present in all the cases (100\%) i.e. complete in $92 \%$, in $4 \%$ incomplete and in $4 \%$ of cases double foramen transversarium was present (Table 1). In four atlas vertebrae (4\%), costal vertebrae showed incomplete foramen transversarium bilaterally. In four vertebrae (4\%), duplication of foramen transversarium were present unilaterally (Fig. 1\&2).

Table 1: Incidence of occurrence of various types of foramen transversarium

\begin{tabular}{|l|c|c|}
\hline $\begin{array}{l}\text { Types of Foramen } \\
\text { Transversarium }\end{array}$ & $\begin{array}{c}\text { Number } \\
\text { Observed }\end{array}$ & Incidence \\
\hline Complete & 92 & $92 \%$ \\
\hline Incomplete & 4 & $4 \%$ \\
\hline Double & 4 & $4 \%$ \\
\hline Absent & 0 & $0 \%$ \\
\hline
\end{tabular}

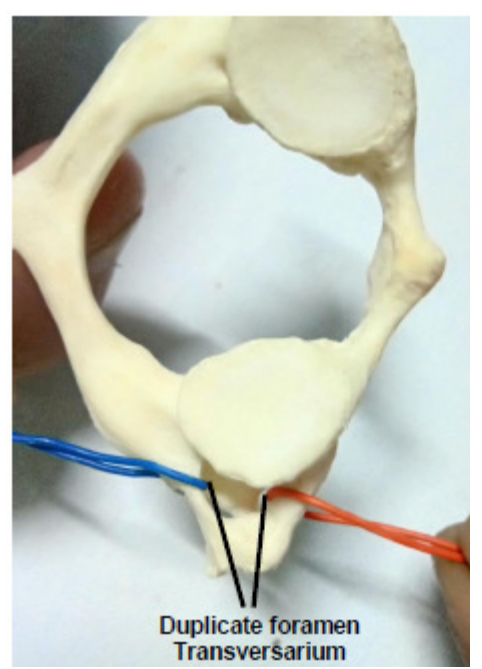

Fig. 1: Photograph showing unilateral duplicate foramen transversarium

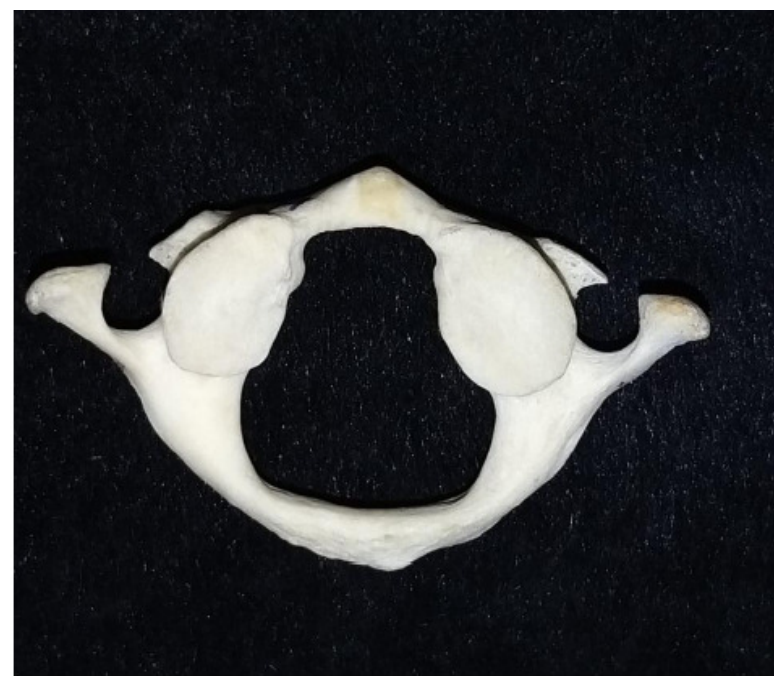

Fig. 2: Photograph showing incomplete foramen transversarium

\section{DISCUSSION}

Variations of atlas vertebrae is common [1], many authors have observed different variations of atlas vertebrae like deficient anterior arch, deficient posterior arch, retroarticular foramen, accessory foramen, duplicated, incomplete or absent foramen transversarium [2-8] (Table 2 \& 3). Zambare and Reddy (2011) studied fifty atlas vertebrae and found complete in $4 \%$ of cases and incomplete ring of foramen in $12 \%$ cases [9]. Chauhan and Khanna (2013) studied fifty atlas vertebrae and found absence of costal element in seven vertebrae [4]. Taitz and Nathan (1986) reported absence of the transverse foramen at C4 and C6 vertebrae [6]. Vasudeva and Kumar (1995) reported unilateral absence of foramen transversarium on the left side of atlas [10]. Nayak (2007) observed bilateral absence of foramen transversarium [11]. But in present study, foramen transversarium were present in all the cases. Aziz and Morgan (2018) observed 7\% incomplete and 17.7\% double foramen transversarium [8]. Sethi et al. (2014) observed $97 \%$ complete, $2 \%$ incomplete and $1 \%$ absent foramen transversarium of atlas vertebrae [5]. Karau and Odula (2013) observed $7.8 \%$ incomplete foramen transversarium [2]. Hasan et al. (2001) observed $8.60 \%$ double foramen transversarium [7]. Gupta et al. (2013) observed $8.57 \%$ incomplete foramen transversarium [3]. But in present study we observed that foramen transversarium was present in all the cases i.e. complete in $92 \%$, in $4 \%$ incomplete and in $4 \%$ of cases double foramen transversarium was present. 
Study of variations in foramen transversarium......

Table 2: Comparison of findings on foramen transversarium of present study with previous studies

\begin{tabular}{|l|c|c|c|}
\hline Authors & Population & $\begin{array}{c}\text { Absent } \\
\text { Foramen } \\
\text { Trans- } \\
\text { versarium }\end{array}$ & $\begin{array}{c}\text { Incomplete } \\
\text { Foramen } \\
\text { Trans- } \\
\text { versarium }\end{array}$ \\
\hline $\begin{array}{l}\text { Karau and } \\
\text { Odula } \\
\text { (2013) [2] }\end{array}$ & Kenyans & 0 & $7.8 \%$ \\
\hline $\begin{array}{l}\text { Gupta et al. } \\
\text { (2013) [3] }\end{array}$ & Indians & - & $8.57 \%$ \\
\hline $\begin{array}{l}\text { Chauhan } \\
\text { and Khanna } \\
\text { (2013) [4] }\end{array}$ & Indians & - & $10 \%$ \\
\hline $\begin{array}{l}\text { Sethi et al. } \\
\text { (2014) [5] }\end{array}$ & Indians & $2 \%$ & $2 \%$ \\
\hline $\begin{array}{l}\text { Present } \\
\text { Study } \\
\text { (2018) }\end{array}$ & Indians & $0 \%$ & $4 \%$ \\
\hline
\end{tabular}

Table 3: Prevalence of double transverse foramina in different study population

\begin{tabular}{|l|c|c|}
\hline Authors & Population & $\begin{array}{c}\text { Prevalence } \\
\text { of double } \\
\text { foramina }\end{array}$ \\
\hline $\begin{array}{l}\text { Taitz and Nathan } \\
\text { (1986) [6] }\end{array}$ & Indians & $7 \%$ \\
\hline Hasan et al. (2001) [7] & Roaman & $8.60 \%$ \\
\hline $\begin{array}{l}\text { Karau and Odula } \\
\text { (2013) [2] }\end{array}$ & Kenyans & $3.90 \%$ \\
\hline $\begin{array}{l}\text { Aziz \& Morgan (2018) } \\
\text { [8] }\end{array}$ & Egyptian & $17.70 \%$ \\
\hline Present Study (2018) & Indians & $4 \%$ \\
\hline
\end{tabular}

\section{CONCLUSION}

It can be concluded from the present study that variations are not uncommon in foramen transverserium of atlas vertebrae. Anatomical variations of atlas vertebrae especially in the bony bridges embracing the vertebral artery and first cervical nerve is common which may be responsible for various neurological disturbances. Knowledge of such variations is important for physicians, otorhinolaryngologists, neurologists and orthpaedicians.

\section{REFERENCES}

1. Chummy S. Sinatamby, Last's Anatomy- Regional and Applied. Head, Neck \& Spine, $11^{\text {th }}$ ed., Churchill Livingstone, 2006, pp$451,470$.

2. Karau PB, Odula P: Some anatomical and morphometric observations in the transverse foramina of the atlas among Kenyans, Anatomy Journal of Africa. 2013; 2 (1): 61-66.

3. Gupta C, Radhakrishnan P, Palimar V, D'Souza AS, Kiruba NL. A quantitative analysis of atlas vertebrae and its abnormalities. J Morph Sci. 2013; 30 (2): 77-81.

4. Chauhan R, Khanna J. Absence of costal element of the foramen transversarium of atlas vertebrae. Int $\mathrm{J}$ Res Med Sci. 2013; 1:66-8.

5. Sethi M, Vasudeva N, Mishra S. Study of foramen transversaria of first cervical vertebrae and its variations. OA Anatomy. 2014; 2 (3): 25.

6. Taitz C, Nathan $\mathrm{H}$. Some observations on the posterior and lateral bridge of the atlas. Acta Anat (Basel). 1986; 127 (3):212217.

7. Hasan M, Shukla S, Siddiqui MS, Singh D. Posterlateral tunnels and ponticuli in human atlas vertebrae. $\mathrm{J}$ anat. 2001; 199:339-343.

8. Aziz JN, Morgan M. Morphological study of foramen transversarium of the atlas vertebra among Egyptian population and its clinical significance, Anat Physiol Biochem Int J. 2018; 4(4).

9. Zambare BR, Reddy BB. The retro-articular ring of atlas and its clinical significance. Anatomica Karnataka. 2011; 5 (2): 74-76.

10. Vasudeva N, Kumar R. Absence of foramen transversarium in the human atlas vertebra: a case report. Acta Anat (Basel). 1995; 152:230-233.

11. Nayak BS. Bilateral absence of foramen transversarium in atlas vertebra: a case report. Neuroanatomy 2007; 6:28-29. 